\title{
The treatment of iron-deficiency anaemia by iron-dextran infusion, with special reference to the effect on blood-grouping, coagulation, sedimentation and haemolysis
}

\author{
BERNARD M. GRODEN \\ M.B., Ch.B., M.R.C.P.G., M.R.C.P.E. \\ JAMES WHITELAW \\ M.B., Ch.B., M.R.C.P.E., M.C.Path., D.Path. \\ GeORGe WiLl \\ M.B., Ch.B., B.Sc., F.R.C.P.G., M.R.C.P.E. \\ Departments of Medicine and Haematology, \\ Southern General Hospital, Glasgow, and a Medical Unit, Gateside Hospital, Greenock
}

\section{Summary}

Fifty patients with iron-deficiency anaemia were treated by total-dose infusion of iron-dextran. The therapeutic response was satisfactory in all cases. No severe systemic side effects occurred. In ten patients in whom detailed investigations were made there was no change in erythrocyte sedimentation rate or blood coagulation nor was there evidence of haemolysis following the irondextran infusion. No difficulty was found in $\mathrm{ABO}$ and $\mathrm{Rh}$ blood grouping and cross matching after infusion.

\section{Introduction}

Oral iron therapy will effect a rapid return to normal of the peripheral blood haemoglobin level in the great majority of cases of irondeficiency anaemia. Since satisfactory treatment of iron deficiency implies replacement of the total body iron deficit however, it is now realized that several months of continuous oral therapy are required to bring about full replacement of the depleted iron stores. Many patients default from treatment before the total body iron deficit has been corrected and patients with continuing blood loss, such as can occur from hiatus hernia, colonic diverticulosis or severe menorrhagia, may require almost permanent oral iron therapy to maintain iron balance. We feel that these factors justify the parenteral treatment of iron-deficiency anaemia in selected cases.

A number of iron preparations for intravenous use have been produced. Earlier intravenous preparations such as colloidal ferric hydroxide and colloidal ferric oxide proved to be too toxic (Goethsch, Moore \& Minnich, 1946) and the first practical form of intravenous therapy was a saccharated iron oxide compound (Nissim, 1947) but even with this substance a significant number of severe toxic reactions occurred (Barrit \& Swain, 1953 ; Librach, 1953 ; Nissim, 1954 ; Ross, 1957 ; Bare \& Sullivan, 1960).

There are two iron compounds available for intramuscular injection, iron-dextran and ironsorbitol-citric acid complex. Both have been used extensively and their safety and effectiveness are established (Baird \& Podmore, 1954; Scott \& Govan, 1954; Grimes \& Hutt, 1957; Andersson, 1961).

Replacement of the total body iron deficit by intramuscular iron therapy requires multiple injections which are tedious to both patient and doctor. Further disadvantages of the intramuscular preparations are loss of iron by local sequestration or in the urine, painful injections which tend to occur particularly in patients whose muscle mass is small, allergic reactions and skin staining.

In an attempt to simplify parenteral iron therapy Basu (1963) introduced the single total dose method of administration using iron-dextran, giving the total estimated body requirement of iron in a single intravenous infusion. Subsequent reports (Marchasin \& Wallerstein, 1964 ; Varde, 1964 ; Bonnar, 1965 ; Dawson, Goldthorpe \& Spencer, 1965; Manson, 1966) have confirmed that intravenous iron-dextran is well tolerated in quantitities containing up to $3 \mathrm{~g}$ of iron. The report by Clay et al. (1965) of frequent severe reactions with this form of therapy is contrary to the general experience. It has been suggested that iron-dextran infusion might cause interference with blood grouping and 
cross-matching tests and erythrocyte sedimentation rate such as occurs after macromolecular dextran infusion for blood-volume replacement. Newcombe (1967) has reported an increased heparin retarded clotting time of plasma which persisted for $24 \mathrm{hr}$ in four patients given $25 \mathrm{ml}$ undiluted iron-dextran intravenously and suggests that after large intravenous doses circulating iron-dextran may exert an anticoagulant effect of clinical importance.

To assess the effectiveness of this form of therapy in iron-deficiency anaemia we have studied the haematological response in fifty patients treated with total iron-dextran infusion. In ten of these patients detailed laboratory investigations were undertaken to detect possible adverse effects of the treatment on red blood cells, blood grouping and cross matching, erythrocyte sedimentation rate, and the coagulation mechanism. In another ten patients a small tracer dose of labelled iron-dextran $\left({ }^{59} \mathrm{Fe}\right)$ was given at the same time, but the results of this experiment have been reported elsewhere (Will \& Groden, 1968).

\section{Materials and methods}

The diagnosis of iron-deficiency anaemia, as in previous reports (Will \& Groden, 1965), was based on peripheral blood findings of low haemoglobin, low mean corpuscular haemoglobin concentration and hypochromia of the stained peripheral blood film associated with abnormally low serum iron level, raised total iron-binding capacity and absence of stainable iron in the marrow. A satisfactory response to iron therapy was the ultimate confirmation of the diagnosis. Standard haematological techniques were used (Dacie \& Lewis, 1963) and serum iron estimations were made by the technique of Ramsay (1957). Tables 1 and 2 summarize the aetiological factors present and the initial haematological details.

The quantities of iron-dextran ranged from 27 to $68 \mathrm{ml}(1.35-3.4 \mathrm{~g}$ iron). The iron preparation was given diluted in $250-1000 \mathrm{ml}$ isotonic saline. The infusion was run at the rate of 10 15 drops per minute for the first $5 \mathrm{~min}$ while the patient was observed for evidence of systemic reaction. The rate was then increased to 45-60 drops a minute until the infusion was completed. Thirty minutes before the infusion was begun forty of the patients were given an antihistamine by intramuscular injection, promethazine hydrochloride (Phenergan) $25 \mathrm{mg}$. After the irondextran infusion the patient was instructed not to take any form of iron therapy.
TABLE 1

Aetiology of iron-deficiency anaemia in fifty patients given iron-dextran infusions

\begin{tabular}{|c|c|c|}
\hline \multirow{2}{*}{ Aetiological factors } & \multicolumn{2}{|c|}{ Sex } \\
\hline & Female & Male \\
\hline Chronic peptic ulcer & 1 & 2 \\
\hline Gastric surgery for peptic ulcer & 2 & 5 \\
\hline Hiatus hernia & 5 & 1 \\
\hline Gastric carcinoma & 1 & 1 \\
\hline Colonic carcinoma & 1 & 1 \\
\hline Colonic diverticulosis & 4 & - \\
\hline Menorrhagia & 11 & - \\
\hline Pregnancy & 2 & - \\
\hline $\begin{array}{l}\text { Iron-deficiency anaemia of the } \\
\text { adolescent male }\end{array}$ & - & 1 \\
\hline Venous malformation of gastric & & \\
\hline mucosa & - & 1 \\
\hline Idiopathic & 11 & - \\
\hline Totals & 38 & 12 \\
\hline
\end{tabular}

The ages of the patients in the idiopathic group ranged from 54 to 71 years.

TABLE 2

Age and sex distribution and initial haemoglobin levels of fifty patients with iron-deficiency anaemia, treated by irondextran infusion

(a) Age and sex distribution of patients

\begin{tabular}{lcccccccc}
\hline & \multicolumn{9}{c}{ Age (years) } & Total \\
\cline { 2 - 6 } & $15-$ & $20-$ & $30-$ & $40-$ & $50-$ & $60-$ & $70-n$ & \\
\hline Female & 1 & 6 & 2 & 6 & 5 & 13 & 5 & 38 \\
Male & 2 & & 1 & 1 & 2 & 5 & 1 & 12 \\
$\quad$ Total & 3 & 6 & 3 & 7 & 7 & 18 & 6 & 50 \\
\hline
\end{tabular}

(b) Initial haemoglobin levels

\begin{tabular}{lcccc}
\hline & \multicolumn{3}{c}{$\mathrm{Hb}(\mathrm{g} / 100 \mathrm{ml})$} & \multirow{2}{*}{ Total } \\
\cline { 2 - 4 } & $4 \cdot 5-6.9$ & $7 \cdot 0-8.9$ & $9 \cdot 0-10 \cdot 4$ & \\
\hline Female & 16 & 16 & 6 & 38 \\
Male & 4 & 4 & 4 & 12 \\
Total & 20 & 20 & 10 & 50 \\
\hline
\end{tabular}

In the ten patients who did not receive an antihistamine drug the following tests were carried out immediately before the drip was set up and were repeated at the end of the infusion: Standard ABO tube grouping tests and $\mathrm{Rh}$ grouping by albumin and papain techniques, erythrocyte sedimentation rate (Westergren), bleeding time (Ivy), whole blood clotting time (Lee and White), one-stage prothrombin time (Quick), and capillary fragility test (Hess). The thromboplastin generation test (Biggs \& Douglas, 1953) was carried out on six of these patients and the 
partial thromboplastin time (Procter \& Rappaport, 1961) on the remaining four, before and at the end of infusion. To detect possible damage to the red blood cells, the serum of these ten patients was examined at the end of the infusion for free haemoglobin using a Hartridge reversion spectroscope and Schumm's test for methaemalbumin was performed $8 \mathrm{hr}$ after the infusion had been completed. The sera of these patients were also tested against papainized $\mathbf{R}_{\mathbf{1}} \mathbf{R}_{\mathbf{2}}$ cells at $37^{\circ} \mathrm{C}$. Two pints of blood were tested for compatibility in each case using patient's serum obtained at the end of infusion, by saline $\left(20^{\circ} \mathrm{C}\right)$, papain $\left(37^{\circ} \mathrm{C}\right)$ and indirect antiglobulin techniques.

\section{Results}

In all patients a satisfactory reticulocyte response occurred and was followed by a progressive rise in haemoglobin. In the majority of patients a significant reticulocyte response had begun by the 4th day after infusion and the peak response usually occurred between the 8th and 10th days.

The mean haemoglobin increments after each of the first 3 weeks of treatment were $1.5 \mathrm{~g}$ (range $0.3-3.5 \mathrm{~g}$ ), $2.7 \mathrm{~g}$ (range $1.0-5.2 \mathrm{~g}$ ) and $3.6 \mathrm{~g}$ (range $1.6-6.8 \mathrm{~g}$ ). When the patients are separated into three groups on the basis of initial haemoglobin levels the rate of response to irondextran is shown to be related to the severity of the anaemia. These results are shown in Table 3.

TABLE 3

Haemoglobin response to iron-dextran infusion

(a) Overall response

\begin{tabular}{cccc}
\hline \multirow{2}{*}{$\begin{array}{c}\text { No. of } \\
\text { patients }\end{array}$} & \multicolumn{4}{l}{ Mean $\mathrm{Hb}$ increment $(\mathrm{g} / 100 \mathrm{ml})$ at: } \\
\cline { 2 - 4 } & 7 days & 14 days & 21 days \\
\hline 50 & 1.5 & 2.7 & 3.6 \\
\hline
\end{tabular}

(b) Haemoglobin response related to the severity of the anaemia

\begin{tabular}{|c|c|c|c|c|}
\hline \multirow{2}{*}{$\begin{array}{l}\text { Initial } \mathrm{Hb} \text { range } \\
\quad(\mathrm{g} / 100 \mathrm{ml})\end{array}$} & \multirow{2}{*}{$\begin{array}{l}\text { No. of } \\
\text { patients }\end{array}$} & \multicolumn{3}{|c|}{$\begin{array}{l}\text { Mean } \mathrm{Hb} \text { increment } \\
(\mathrm{g} / 100 \mathrm{ml}) \text { at: }\end{array}$} \\
\hline & & 7 days & 14 days & 21 days \\
\hline $\begin{array}{l}4 \cdot 5-6 \cdot 9 \\
7 \cdot 0-8 \cdot 9 \\
9 \cdot 0-10 \cdot 4\end{array}$ & $\begin{array}{l}20 \\
20 \\
10\end{array}$ & $\begin{array}{l}2 \cdot 0 \\
1 \cdot 3 \\
1 \cdot 1\end{array}$ & $\begin{array}{l}3 \cdot 5 \\
2 \cdot 4 \\
1 \cdot 8\end{array}$ & $\begin{array}{l}4 \cdot 3 \\
3 \cdot 4 \\
2 \cdot 5\end{array}$ \\
\hline
\end{tabular}

One patient defaulted after 14 days. In the remaining forty-nine patients for whom full data are available the haemoglobin had reached normal levels by the 9th week. When seen 16 weeks after the infusion the remaining patient had a normal haemoglobin level.

In the ten patients investigated no significant change from the pre-infusion results were detected in the tests of bleeding time, clotting time, one-stage prothrombin time, capillary fragility, thromboplastin generation or partial thromboplastin time. The ESR estimations remained unchanged and there was no evidence of intravascular haemolysis following infusion. No difficulty was experienced in carrying out $\mathrm{ABO}$ and $\mathrm{Rh}$ grouping and cross matching of blood in any of the ten patients using blood samples withdrawn immediately after completion of the irondextran infusions (Table 4).

There were no general systemic reactions during or after the infusions. One patient complained of frontal headaches coming on half-an-hour after completion of the infusion. Superficial thrombophlebitis occurred in five patients, only two of whom had received an antihistamine injection before treatment.

\section{Discussion}

The absence of signs of iron toxicity in the immediate post-infusion period when the plasma iron-dextran content is at its highest is in keeping with the suggestion that the complex circulates in the blood stream as inert material until it is taken up by the reticulo-endothelial system (Golberg, 1958). The prompt occurrence of a reticulocyte response with peak values attained between the 8th and 10th days shows clearly that despite the firm union of the iron with the dextran, there is no delay in iron utilization. The haemoglobin increments measured over the first 3 weeks after treatment exceed those reported in similar cases by other workers using a variety of parenteral iron preparations (Kartchner \& Holmstrom, 1950 ; Scott \& Govan, 1951 ; Jennison \& Ellis, 1954 ; Scott \& Govan, 1954 ; Scott, 1956 ; Andersson, 1961).

The initial rate of rise of haemoglobin reported is considerably faster than the figure of $2 \mathrm{~g}$ / $100 \mathrm{ml}$ at the end of 3 weeks which is regarded by Coleman et al. (1955) as a significant response to oral iron therapy, while Goldberg (1967) defines a satisfactory response to oral iron therapy as an increase in the haemoglobin level of about $1 \%$ per day with a rise of at least $10 \%(1.5 \mathrm{~g} /$ $100 \mathrm{ml}$ ) within 3 weeks. It appears to us, however, that the principal advantage of iron-dextran infusion is not the faster initial rate of haemoglobin rise but the ability to give the total iron requirement to the patient within a few hours, including enough iron to replenish completely the depleted body iron stores. 


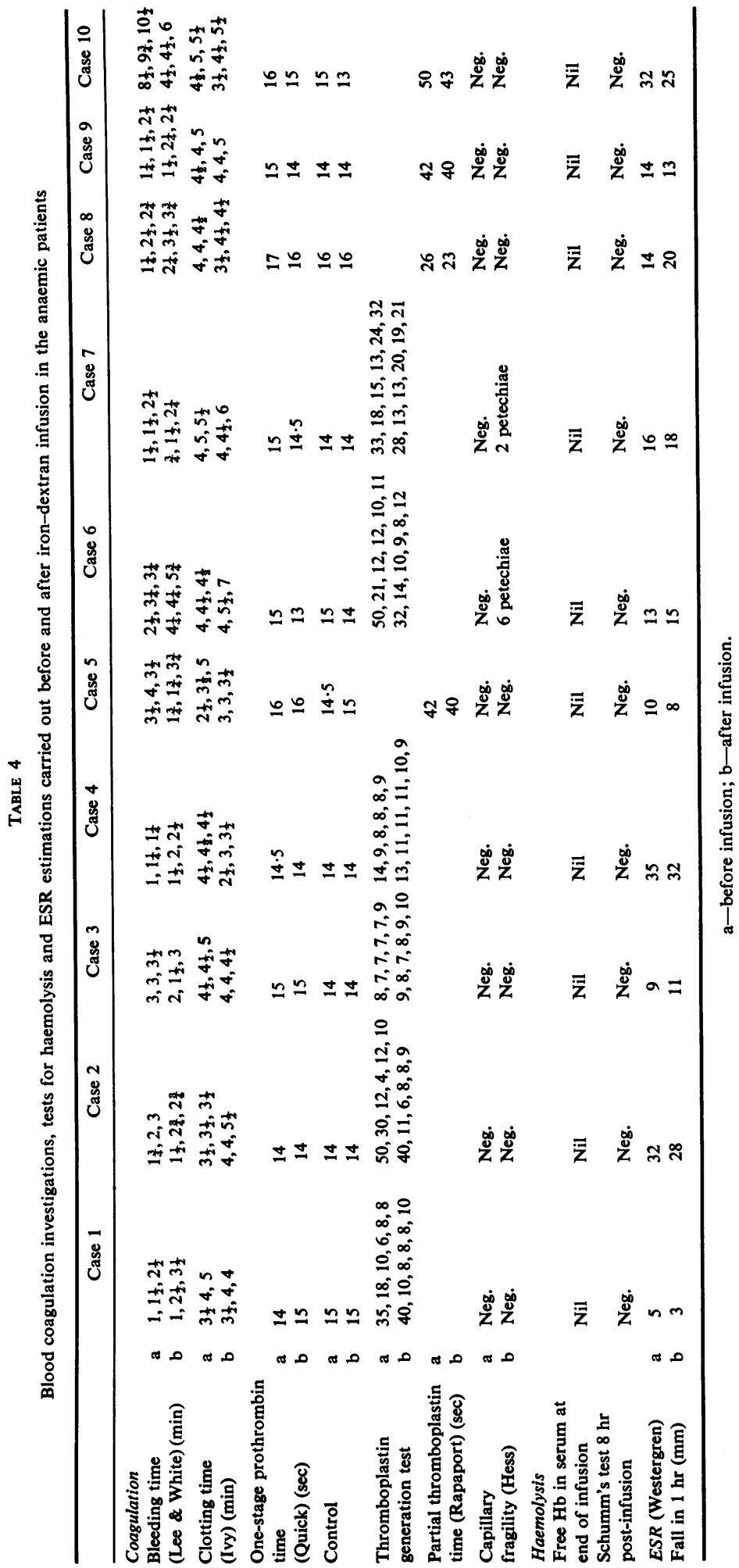


The adequacy of the haematological response in iron deficiency anaemia to total-dose irondextran infusion has been previously reported by a number of authors (Gartlan, 1964 ; Varde, 1964 ; Basu, 1965 ; Bonnar, 1965 ; Clay et al., 1965 ; Goldthorp, Spencer \& Dawson, 1965 ; Lane \& Scott, 1965; Manson, 1965), but these studies related to patients seen in obstetric and gynaecological practice. The results in the present series indicate that a similar satisfactory response can be obtained in patients within a wide age range and suffering from a variety of clinical conditions.

No severe reactions occurred during or following the infusions. The incidence of local phlebitis was low and when it occurred was mild in type. The time taken to complete the infusion ranged from $30 \mathrm{~min}$ to several hours. No increase in complications occurred in the patients given the iron-dextran more rapidly and we doubt the rationale of prolonging the infusion. Indeed we gained the impression that the incidence of thrombophlebitis was lower in the patients rapidly infused.

Blood grouping and cross matching and the erythrocyte sedimentation rate were not influenced by the treatment in the ten patients investigated. The coagulation mechanism was not impaired nor was there evidence of intravascular haemolysis. It seems that with the dosage of iron-dextran required to treat iron deficiency the amount of dextran present in the circulation after the infusion is insufficient to cause enhanced rouleaux-formation or to alter the clotting mechanism when this is tested by the methods described.

\section{References}

ANDERsson, N.S.E. (1961) Clinical investigations on a new intramuscular haematinic. Brit. med. J. ii, 275.

BAIRD, I. MCL. \& PODMORE, D.A. (1954) Intramuscular iron therapy in iron-deficiency anaemia. Lancet, ii, 942.

Bare, W.W. \& Sullivan, A.A. (1960) Comparison of intravenous saccharated iron oxide and whole blood in treatment of hypochromic anaemia of pregnancy. Amer. J. Obstet. Gynec. 79, 279.

BARRIT, D.W. \& SwaIN, G.C. (1953) Death after intravenous iron. Brit. med. J. i, 379.

BASU, S.K. (1963) Rapid administration of iron-dextran in late pregnancy. Lancet, $\mathrm{i}, 1430$.

BAsU, S.K. (1965) Administration of iron-dextran complex by continuous intravenous infusion.J. Obstet. Gynaec. Brit. Cwlth, 72, 253.

Briggs, R. \& Douglas, A.S. (1953) The thromboplastin generation test. J. clin. Path. 6, 23.

BoNNAR, J. (1965) Anaemia in obstetrics: an evaluation of treatment by iron-dextran infusion. Brit. med. J. ii, 1030.
Clay, B., Rosenberg, B., Sampson, N. \& Samuels, S.I. (1965) Reactions to total dose intravenous infusion of iron-dextran (Imferon). Brit. med. J. i, 29.

Coleman, D.G., Stevens, A.R. \& Finch, C.A. (1955) The treatment of iron deficiency anaemia. Blood, 10, 567.

DACIE, J.V. \& LeWIS, S.M. (1963) Practical Haematology, 3rd edn. Churchill, London.

Dawson, D.W., GoldThorP, W.O. \& Spencer, D. (1965) Parenteral iron therapy in pregnancy. J. Obstet. Gynaec. Brit. Cwlth, 72, 89.

Gartlan, G.J. (1964) Parenteral iron in pregnancy. Brit. med. $J$. i, 435.

GoetsCh, A.T., Moore, C.V. \& MinNich, V. (1946) Observations on the effect of massive doses of iron given intravenously to patients with hypochromic anaemia. Blood, 1, 129.

Golberg, L. (1958) Iron in Clinical Medicine (Ed. by R. O. Wallerstein and S. R. Mettier), p. 74. Berkeley, California.

GoldberG, A. (1967) Iron deficiency anaemia. Technical advances. Medical News Magazine, p. 12.

Goldthorpe, W.O., SPencer, D. \& DAWson, D.W. (1965) Reactions to intravenous iron-dextran. Brit. med.J. 1, 316.

Grimes, A.J. \& HuTT, M.S.R. (1957) Metabolism of 59 Fe-dextran complex in human subjects. Brit. med.J. ii, 275.

JenNison, R.F. \& Ellis, H.R. (1954) Intramuscular iron, a clinical trial in pregnancy. Lancet, ii, 1245.

KARTCHNER, F.D. \& Holmstrom, E.G. (1950) The treatment of iron deficiency anaemia of pregnancy with intravenous iron. Amer. J. Obstet. Gynec. 60, 1288.

LANE, R.S. \& ScotT, J.M. (1965) Reactions to intravenous iron-dextran. Brit. med. J. i, 449.

LiBRACH, I.M. (1953) Toxic reactions due to intravenous iron. Brit. med. J. i, 21.

Manson, I.W. (1965) Reactions to intravenous iron dextran. Brit. med. J. i, 794.

Manson, I.W. (1966) Total dose infusion with iron-dextran complex in pregnancy and the puerperium. Med.J. Aust. 53, 174.

Marchasin, S. \& Wallerstein, R.O. (1964) The treatment of iron-deficiency anaemia with intravenous iron-dextran. Blood, 23, 354.

Newcombe, R. (1967) Precautions in the intravenous use of iron-dextran. Postgrad. med. J. 43, 372.

Nissim, J.A. (1947) Intravenous administration of iron. Lancet, ii, 49.

Nissim, J.A. (1954) Toxic reactions after intravenous saccharated iron oxide in man. Brit. med. J. i, 352.

Proctor, R.R. \& RAPPAPORT, S.I. (1961) The partial thromboplastin time with Kaolin. Amer. J. clin. Path. 36, 212.

RamsaY, W.N. (1957) The determination of iron in blood plasma or serum. Clin. chim. Acta, 2, 214.

Ross, I.P. (1957) Toxic reactions after intravenous iron. Lancet, ii, 77.

ScoTT, J.M. (1956) Intramuscular iron therapy in anaemia of pregnancy, two-year survey. Brit. med. J. ii, 635 .

ScotT, J.M. \& GovaN, A.D.T. (1951) Anaemia of pregnancy treated with intravenous iron. Lancet, i, 367.

ScoTT, J.M. \& GovaN, A.D.T. (1954) Anaemia of pregnancy treated with intramuscular iron. Brit. med. J. ii, 1257.

VARDE, K.N. (1964) Treatment of 300 cases of iron deficiency anaemia of pregnancy by total dose infusion of irondextran complex. J. Obstet. Gynaec. Brit. Cwlth, 71, 919.

WiLl, G. \& Groden, B.M. (1965) Benign hypochromic anaemia in the adult male. Scot. med. J. 10, 21.

WILL, G. \& GRODEN, B.M. (1968) The treatment of iron deficiency anaemia by iron-dextran infusion. A radioisotope study. Brit. J. Haemat. 14, 61. 